\title{
Managing social-ecological systems under uncertainty: implementation in the real world
}

\author{
Ana Nuno $^{1}$, Nils Bunnefeld $^{2}$ and EJ Milner-Gulland ${ }^{1}$
}

\begin{abstract}
Management decisions for natural resources are not made in a vacuum; the environmental and ecological conditions as well as the socioeconomic and political contexts affect goals, the choice of interventions, their feasibility, and which outcomes are obtained. Although uncertainty is recognized as a feature of natural resource management, little attention has been given to the uncertainty generated by institutional settings, historical contingency, and individual people's influence. These implementation uncertainties, related to the translation of policy into practice, make it difficult to predict the outcomes of management interventions within social-ecological systems. Using the conservation of species hunted for bushmeat in the Serengeti as a case study, we investigated the challenges and potential barriers to successful implementation of natural resource management policies. We used a mixed-methods approach, combining semistructured interviews with scenario building, social network, and institutional analysis exercises. Using a management strategy evaluation (MSE) conceptual framework, we obtained insights into the constraints and opportunities for fulfilling stakeholder aspirations for the social-ecological system, analyzed the multiple roles played by different institutions in the system, and described the interactions between different actor types. We found that the respondents had generally similar views about the current and future status of the Serengeti but disagreed about how to address issues of conservation concern and were more uncertain about the actual outcomes of management interventions. Improving conservation implementation (rather than research, monitoring, or status assessment) was perceived as the key priority to be addressed. Institutional barriers were perceived as an important challenge given that the decision-making and implementation processes were broadly distributed across a number of institutions. Conservation social networks were centered on very few individuals, suggesting their importance in bridging across conservation arenas but also potentially affecting the resilience of governance structures. Our study gives an improved understanding of the underlying causes of discrepancies between conservation plans and outcomes for this case study, as well as providing a novel framework for the analysis of implementation uncertainties more broadly. A next step would be to use this framework as a basis for collaboratively developed models that integrate research findings with specific management questions. By bringing tools and findings from social psychology, natural resource management, and bioeconomics together into a unified operational framework, researchers may be better able to understand the barriers to successful resource management and engage with stakeholders to overcome them.
\end{abstract}

Key Words: bushmeat; implementation uncertainty; institutions; knowing-doing gap; management strategy evaluation; protected area management; Serengeti; social-ecological modeling; social networks; stakeholders

\section{INTRODUCTION}

Traditional approaches to natural resource management and conservation often assume that managers can accurately predict system responses to their actions and to external drivers (Walker et al. 2002). However, social-ecological systems behave as complex adaptive systems composed of multiple interacting agents (Walker and Janssen 2002), and uncertainties might be large and diverse (Harwood and Stokes 2003, Fulton et al. 2011). The implementation of successful actions is, thus, challenging; the achieved outcomes are sometimes very different from those expected (Armsworth et al. 2006) and, despite the widespread biodiversity loss and threats to many ecosystems (Cardinale et al. 2012), planned interventions are often not even implemented (Arlettaz et al. 2010). The translation of science and policy into practice still lags behind conservation needs and expectations (Knight et al. 2008), and understanding what constrains conservation implementation is an essential step toward achieving successful outcomes.

A "great divide" between science and action has often been described as a major barrier to achieving successful conservation outcomes (Pullin et al. 2004, Knight et al. 2006). Several reasons have been suggested for the existence of this researchimplementation gap, such as the lack of communication and engagement between researchers and practitioners, absence of commitment by researchers themselves to engage in conservation implementation, and insufficient consideration of social dimensions (Knight et al. 2008, Arlettaz et al. 2010). However, even when researchers and practitioners work together, challenging institutional settings, lack of economic, social, and political support and poor governance (referring to the processes and institutions through which societies make decisions; Armitage et al. 2012) may jeopardize implementation (Young 1998, Arlettaz et al. 2010). For example, institutional complexity has been suggested as a driver of inefficient use of resources and intervention ineffectiveness when addressing desertification in Mediterranean countries (Briassoulis 2004). These institutional and implementation uncertainties, related to the translation of policy into practice and arising from interactions between different groups and the different sets of rules governing their behavior (Cochrane 1999, Bunnefeld et al. 2011), may greatly affect conservation outcomes and managers' ability to design effective strategies (Young 1998, Harwood and Stokes 2003, Fulton et al. 2011).

To better understand and improve conservation implementation, it is necessary to assess the social-ecological structure and dynamics of the systems under consideration, as well as to elicit 
the perspectives of multiple actors (Knight et al. 2006, Ban et al. 2013). There can be several people undertaking conservation actions, often with divergent or only partially overlapping objectives, and individual differences in perspectives are often one of the reasons for conflict impeding successful interventions (Adams et al. 2003, Redpath et al. 2013). Identifying areas of agreement and disagreement between actors helps in understanding and overcoming obstacles between them; it provides insights about the perceived probability of particular outcomes from ongoing and potential interventions, and people's willingness to accept these outcomes (Biggs et al. 2011). Additionally, assessing the way these actors perceive institutional interactions may provide insights into how the system works, decision-making processes, and the potential constraints to successful conservation action.

This understanding is at the core of the development and implementation of more holistic approaches to conservation, such as management strategy evaluation (MSE; Butterworth and Punt 1999, Bunnefeld et al. 2011) and adaptive management (AM; Walters 2007, Keith et al. 2011). Both take into account the relationships between and within system components in a more integrated and comprehensive way than traditional approaches to natural resource management, explicitly considering uncertainty, feedbacks between components, and trade-offs between decisions. Management strategy evaluation tests the robustness of potential management strategies to a range of uncertainties by modeling the whole management system: the dynamics of the natural resources and their harvest ("operating model"), their monitoring ("observation model"), how this information is used to inform management decisions ("assessment model"), and how these decisions are implemented ("implementation model"). Conceptual frameworks in MSE can be designed to emphasize the perspectives of different groups within the system (e.g., "resource users," "managers," and "monitors"; Fig. 1). Despite having been used primarily as a quantitative modeling approach within fisheries science, MSE has potential as a flexible and intuitive conceptual framework for analyzing the interactions between stakeholders (Milner-Gulland 2011, Bunnefeld et al. 2011, Plagányi et al. 2013).

Fig. 1. A diagram of the management strategy evaluation (MSE) conceptual framework used in this study.

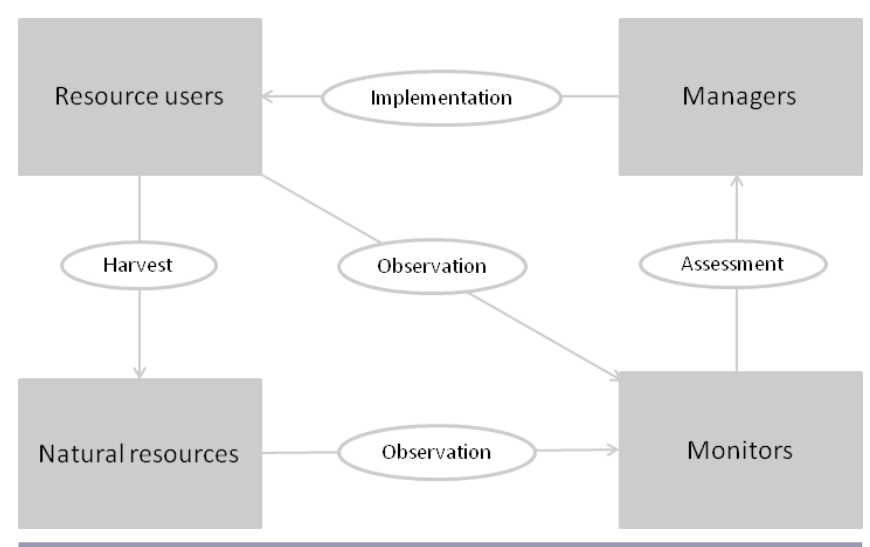

Although MSE has been developed as a simulation-based tool to test alternative management strategies in fisheries (Smith 1999), AM tests alternative strategies in the real world; based on structured "learning by doing," AM considers two or more strategies, monitors them, and then uses information on system dynamics to improve management actions and outcomes (Keith et al. 2011, Allen et al. 2011, Westgate et al. 2013). Despite being widely advocated, AM has been relatively little used in practice (Walters 2007). Institutional barriers are among the major impediments to its implementation (Keith et al. 2011). Lack of leadership, unwillingness to embrace uncertainty, and lack of a long-term vision are also often suggested as causes for the failure to implement AM (Walters 2007, Allen and Gunderson 2011).

In complex social-ecological systems, where adaptive conservation approaches such as MSE and AM are most needed, a range of personal, capacity, and institutional barriers might reduce conservationists' capacity to achieve their expected outcomes with high predictability, potentially playing an important role in explaining the failure to implement successful conservation interventions. Using the bushmeat hunting system in the Serengeti as a case study, we used a MSE framework as a conceptual model to investigate the challenges and potential barriers to successful conservation implementation. Focusing on actors who are responsible for making or influencing rules and their implementation, i.e., those on the management and monitoring sides of the social-ecological system (Fig. 1), we obtained insights into the constraints and opportunities for fulfilling stakeholder aspirations for the system. Then, we analyzed the multiple roles played by different formal institutions in the system, described the interactions between different actor types and summarized the main challenges to implementation of conservation action. Finally, we provide recommendations for the development and implementation of conservation interventions within long-term integrated and adaptive frameworks.

\section{METHODS}

\section{Study System}

Well known for its spectacular wildebeest (Connochaetes taurinus) migration and for having some of the largest herbivore and carnivore populations in the world, the Serengeti is one of the most emblematic social-ecological systems and has attracted the attention of explorers, missionaries, hunters, researchers, and tourists over the last 150 years (Sinclair 2012). The Serengeti national park (SENAPA) was proclaimed in 1951. In 1959, the boundaries of the national park were realigned to include the area of what was assumed to be the migratory route of the wildebeest, which acts as a keystone species of the Serengeti ecosystem (Sinclair 2003, Thirgood et al. 2004). People living inside the park were evicted by 1960 (Shetler 2007). In 1981, SENAPA was internationally recognized as part of a World Heritage Site and a Biosphere Reserve. Nowadays, SENAPA is one of the most visited protected areas in the world (United Nations Development Programme (UNDP) 2012), and its importance for biodiversity conservation, development, and cultural heritage is widely acknowledged (Shetler 2007, Sinclair et al. 2007). The Serengeti ecosystem is one of the most intensively studied systems in Africa; monitoring and research have been conducted since the 1950s, producing several long-term biological data sets and hundreds of 
scientific publications and reports (Sinclair et al. 2007, Sinclair 2012).

All natural resource use within SENAPA has been prohibited since the park's establishment. The Tanzanian side of the ecosystem, the focus of our study, also includes protected multiple-use areas and village areas with agricultural and livestock systems, and with a range of different restrictions on hunting and settlement (Fig. 2; Ministry of Natural Resources and Tourism (MNRT) 1998, Polasky et al. 2008). The establishment and enforcement of these restrictions has not been without difficulties; they have been debated since the establishment of the national park and characterized by a history of conflicts and power struggles over the use, control, and management of lands and resources, influenced by international interests (Nelson and Makko 2005, Shetler 2007). For example, a recently proposed highway crossing the Serengeti generated controversy about trade-offs between different development pathways and their ecological impacts (Dobson et al. 2010, Homewood et al. 2010, Fyumagwa et al. 2013). This attracted the attention of international media (over 1000 press articles published in 48 countries in the 8 mo following its announcement; Sinclair 2012) and catalyzed interventions by the World Bank and the German government.

Fig. 2. Protected areas and lakes (darkest gray) within and surrounding the Serengeti ecosystem. SNP = Serengeti National Park, LGCA = Loliondo Game Controlled Area, $\mathrm{NCA}=$ Ngorongoro Conservation Area, $\mathrm{MGR}=$ Maswa Game Reserve, GGR = Grumeti Game Reserve, IWMA= Ikona Wildlife Management Area, MWMA= Makao Wildlife Management Area, and IGR = Ikorongo Game Reserve. Dashed arrows indicate broad wildebeest migration patterns.

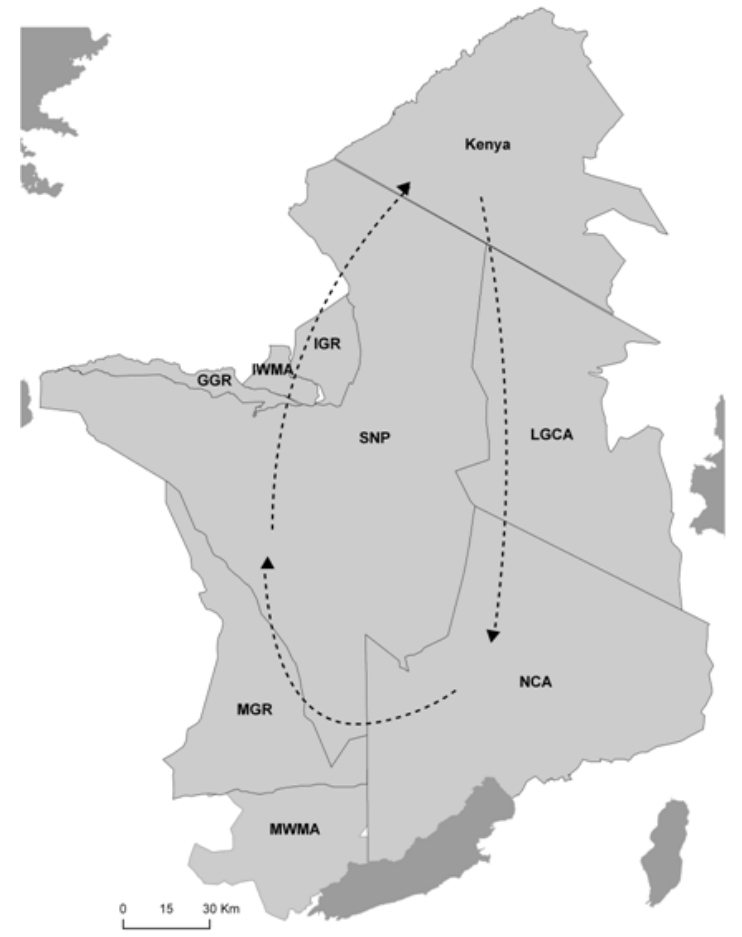

When making decisions about the Serengeti, a great number of interests are at stake; 106 groups of institutional stakeholders were identified in a study by the Serengeti Ecosystem Management Project (SEMP 2006). The protected areas are managed by a range of governmental, nongovernmental, and private sector organizations. Tanzania National Parks (TANAPA) is a parastatal organization responsible for managing and regulating national parks, whereas the Ngorongoro Conservation Area Authority (NCAA) oversees wildlife conservation in the Ngorongoro Conservation Area (NCA). The Wildlife Division (WD) of the MNRT has oversight of game reserves (GRs), game-controlled areas (GCAs) and wildlife management areas (WMAs). The Tanzania Wildlife Research Institute (TAWIRI) is a parastatal organization under the MNRT responsible for conducting and coordinating wildlife research and advising the government and wildlife management authorities. Private tourism and hunting companies, such as Singita Grumeti Reserves, manage the GRs and enter into contracts with communities within other multiple-use areas. Frankfurt Zoological Society (FZS) is one of the most prominent international nongovernmental organizations operating in the Serengeti, active in the system since the 1950s. A number of international donors and national and international research projects provide financial support and advice for park management and conservation interventions, complementing the main source of revenue from tourism (Thirgood et al. 2008).

With roughly 2.3 million people in the districts surrounding the national park and a population growth rate of approximately $3 \%$ (National Bureau of Statistics Tanzania 2006), conflicts over land and natural resources are substantial and expected to grow (Polasky et al. 2008). Bushmeat is, in theory, a state-controlled natural resource in Tanzania, and hunters must obtain a licence for hunting according to quotas set annually by the WD. However, illegal hunting is widespread throughout the Serengeti (Loibooki et al. 2002, Nuno et al. 2013) and has been perceived as a threat to wildlife for several decades (Watson 1965, Arcese et al. 1995, Hilborn et al. 2006). In the past, game cropping schemes have been used, without success, in an attempt to reduce bushmeat hunting (Holmern et al. 2002). The main ongoing initiatives aimed at controlling illegal hunting, which vary in temporal and spatial scale, include: law enforcement carried out by TANAPA rangers and personnel of the GRs; Community Conservation Banks (COCOBAs; facilitated by FZS and based on a lending model that provides access to microcredit for environmentally friendly enterprises); WMAs; Community Conservation Services (CCSes; program conducted by TANAPA to share benefits with communities surrounding SENAPA); and several outreach and environmental education programs (e.g., one conducted by Grumeti Fund, a local NGO associated to Singita Grumeti Reserves). Nevertheless, the high levels of poaching estimated in the area (estimated as being part of the livelihoods of $18 \%$ of households) suggest that bushmeat hunting remains an issue to be addressed (Nuno et al. 2013), and the effectiveness of these interventions has been difficult to ascertain and potentially limited to localized areas (but see Hilborn et al. (2006) on the positive effects of antipoaching activities on wildlife abundance in the national park). 


\section{Study Design}

Using the bushmeat hunting system in the Serengeti as a case study, we investigated the challenges and potential barriers to successful conservation implementation according to main actors in the monitoring and management components of the MSE framework (Fig. 1). We used key-informant interviews to elicit potential and desired scenarios for the study system (scenariobuilding exercise), to understand the actual and perceived roles of different organizations within the system and how they fit in the MSE framework (institutional analysis exercise), and to analyze institutional interplay, social network composition, and complexity (social network analysis). Throughout the study, we used the following terms and definitions: a policy is an overall plan defining goals and procedures and used to guide decisions; a plan is a proposal or intention for doing something; an intervention is an action or process that is carried out to influence what happens; and implementation is the execution of a plan or decision.

\section{Study participants}

Given the institutional complexity and number of stakeholders involved in the Serengeti, we chose to interview actors from the four main organizations operating in the Serengeti, who are responsible for making or influencing rules affecting bushmeat hunting in the Western Serengeti; FZS, TAWIRI, TANAPA and Grumeti Fund, and actors from closely collaborating universities. Local people were not interviewed because, although some members of local communities are involved in WMA decisions, this process is still incipient and at a very local scale. Targeted sampling was used to select respondents, who were invited to participate if they were directly involved in management, monitoring, or research in the Serengeti and connected to ongoing conservation actions. The number of interviews per organization is not proportional to its size; it represents the number of people familiar with the topics under discussion, ensuring coverage of different roles within the organizations, and their availability to be interviewed.

Nineteen interviews were conducted. The average age of the respondents was 44 years, and half had more than 5 years of experience working in the Serengeti. A summary of the study participants is presented in Table 1 .

\section{Data collection and analyses}

All exercises were carried out with individual respondents in private. Study participants were presented with a few questions about their role within the study system, academic background, and sociodemographic characteristics, followed by the three exercises (scenario building, institutional analysis, and social network analysis). Then, semistructured interviews were conducted to promote further discussion around the MSE framework and its components. All questions from the exercises and semistructured interviews are presented in Appendices 1 and 2. Consent for participation and audio recording were obtained before each discussion. Total interview time ranged from $36 \mathrm{~min}$ to $1 \mathrm{~h} 40 \mathrm{~min}$. All interviews were conducted in English by A.N.

\section{Scenario building}

Scenario building is a useful tool to ask respondents to consider different futures and assess their desirability and achievability given certain conditions (Peterson et al. 2003). This exercise aimed to assess expected (what they thought would happen) and desired (what they wanted to happen) scenarios for the study system
Table 1. Summary of the main characteristics of study participants $(n=19)$

\begin{tabular}{|c|c|c|}
\hline Characteristics & Level & Count \\
\hline \multirow[t]{5}{*}{ Organization } & FZS & 7 \\
\hline & TAWIRI & 6 \\
\hline & Universities & 3 \\
\hline & TANAPA & 2 \\
\hline & Grumeti Fund & 1 \\
\hline \multirow{4}{*}{$\begin{array}{l}\text { Main type of } \\
\text { role }^{a}\end{array}$} & Research & 11 \\
\hline & Coordination/management & 9 \\
\hline & Fieldwork & 3 \\
\hline & Administration & 2 \\
\hline \multirow[t]{6}{*}{ Area of work ${ }^{a}$} & Livelihoods and engagement & 12 \\
\hline & with communities & 9 \\
\hline & Wildlife monitoring and & 7 \\
\hline & management & 2 \\
\hline & Academic & \\
\hline & Anti-poaching & \\
\hline Disciplinary & Mainly ecological (e.g., & 13 \\
\hline \multirow[t]{3}{*}{ background } & Wildlife management) & 4 \\
\hline & Interdisciplinary & 2 \\
\hline & $\begin{array}{l}\text { Mainly social (e.g., Applied } \\
\text { economics) }\end{array}$ & \\
\hline \multirow[t]{2}{*}{ Nationality } & Tanzanian & 12 \\
\hline & Other countries & 7 \\
\hline \multirow[t]{2}{*}{ Sex } & Male & 14 \\
\hline & Female & 5 \\
\hline
\end{tabular}

${ }^{a}$ Each respondent could choose more than one option, so total count exceeds sample size.

according to multiple actors. This allowed us to identify the main areas of agreement, disagreement, and uncertainty among actors, as well as gather information about potential threats and management strategies in the future and investigate how goals for the system were set by each respondent. First, the respondents were asked to describe scenarios for the overall Serengeti ecosystem, and then to focus specifically on scenarios for bushmeat hunting, the ecosystem's ecological value, and poverty, as we were interested in knowing how these key issues, and potential trade-offs among them, were considered by different actors. After describing these scenarios, the respondents were asked what constrained movement from the expected to the ideal situation in order to obtain their overall opinions about key challenges to the system, particularly with respect to implementation issues (Appendix 1).

\section{Institutional analysis}

Institutional analysis is often conducted to identify and represent stakeholders' perceptions of key institutions inside and outside a system and their relationship and importance, allowing researchers to understand how different participants perceive institutions differently (Holland 2007). This exercise aimed to identify key formal institutions operating in the system, how they overlap with each other in each MSE subcomponent, and their perceived importance. Participants were asked to list the 
institutions operating in the bushmeat hunting system, indicate the subcomponents of the MSE framework in which they were involved (Fig. 1), and indicate whether they played a weak, medium, or strong role (scored as 1,2 , or 3 , respectively) in decision making and intervention implementation in the study system.

The institutions listed by different actors in the institutional analysis exercise were ranked according to their role in decision making and implementation by weighting them based on their perceived importance for each process. Not being mentioned by a specific actor was scored as 0 .

\section{Social network analysis}

Social networks can be used to characterize collaborations and social relationships, to facilitate conservation, and to identify potential challenges to its implementation (Bodin and Crona 2009, Guerrero et al. 2013). This exercise aimed to identify the role and influence of different actors and their organizations according to their positions within the network, as well as to obtain a measure of system connectivity. Each respondent was asked to list up to 10 collaborators in projects about the Serengeti (people with whom they exchanged information aiming to seek or provide advice and support, influence policy, and/or implement interventions) and to indicate the frequency and nature of the collaboration (Appendix 1).

Social network analyses were conducted using the igraph package, version 0.6.5-1 in R v.2.15.2 (The R Foundation for Statistical Computing 2012). The analyses were conducted separately for the overall network (including all collaborators listed in the exercise) and for each of the subset networks obtained by asking the participants to indicate the main reasons for collaborating with each person ("advice and support network," "policy network," and "implementation network"). The intensity of the links in the social networks was measured using the frequency of interactions. To describe the structure of the networks, we measured the number of links, edge connectivity (also known as group adhesion; minimum number of directed links needed to remove all directed paths between two individuals), density (number of reported links as a percentage of the total possible links), and the mean geodesic distance (the shortest path through the network from one individual to another). To assess individual positions in the networks, we measured actor degree (the number of direct connections a person has), eigenvector centrality (based on the number of direct connections a person has but also on the centrality of those nodes), and betweenness centrality (how many times an actor rests on a short path connecting two others who are themselves disconnected) as indicators of centrality and influence (O’Malley and Marsden 2008, Prell et al. 2009).

\section{Semistructured interviews}

To promote further discussion, open-ended questions were used to gather information about the personal experiences and perceptions of each respondent while working in the Serengeti. These questions focused on the overall study system and its multiple subcomponents according to the MSE framework (topic guide available in Appendix 2). In particular, we aimed to gather information about the main issues characterizing and constraining conservation implementation.

After interview transcription, all texts were analyzed and managed in NVivo10 (QSR International Inc., Burlington,
Massachusetts, USA) using principles of thematic analysis and an inductive approach (Bernard 2011), in which data-driven categories (codes) are identified, compared, and grouped in order to create a typology of the main issues.

\section{RESULTS}

\section{Actors' Perspectives about the Serengeti Ecosystem}

During the description of expected and desired scenarios for the Serengeti, the respondents expressed generally similar views about the current and future status of the Serengeti ecosystem and its multiple functions and value for biodiversity, local livelihoods, and tourism. The respondents also shared similar views about the overall functioning of the ecosystem and the need to address bushmeat hunting and poverty in local communities. When asked to list the top threats to the Serengeti, increasing human population growth, land-use conflicts, and poaching were the most frequently mentioned (Appendix 3). Ten out of 19 participants listed bushmeat hunting as a top threat. Poor management and governance (e.g., dependence on unstable funding; institutional complexity; instability in policies) were mentioned as a top threat by six respondents. The listed top threats can be broadly grouped into the following, often interrelated, categories: human population growth; land-use conflicts and encroachment; poaching; climate change and environmental stress; development, infrastructures, and tourism; poor management and governance; poverty and lack of opportunities; diseases; habitat degradation and water scarcity; invasive species; human-wildlife conflict; and mining.

The main areas of disagreement and uncertainty were related to how exactly issues of conservation concern should be addressed. For example, the respondents had differing opinions about the type and amount of human engagement that should be allowed in the system, either through management or resource use. Also, although some respondents suggested the need to emphasize the instrumental reasons for conserving the Serengeti (e.g., tourism revenue and its importance for the national economy), others suggested that conservation actions should be driven only by their intrinsic value. Additionally, the role of international bodies was generally described as advisory, but some respondents suggested that only through the pressure and action of these bodies will the Serengeti be maintained in the future. A key area of uncertainty discussed by all respondents was the need to identify and develop sustainable models of development that maximize, or at least do not jeopardize, biodiversity. For example, some respondents suggested that wildlife-related activities (e.g., tourism) are essential for community development, whereas others mentioned that other approaches should be used instead, in which communities are not dependent on wildlife at all. Disagreement between participants did not seem to be related to their institutional affiliation. Scenarios and the main areas of agreement, disagreement, and uncertainty are presented in Table 2.

\section{Constraints to Reaching Preferred Scenarios}

During the interviews, implementation was identified as the main gap that should be addressed for successful conservation of the Serengeti ("However good a plan is, if something else doesn't go properly, the plan will just be there"), followed by doing more research on topics such as climate change, invasive species, diseases, and social dynamics, and disseminating research 
Table 2. Summary of the expected and desired scenarios described by the respondents, indicating main areas of agreement, disagreement, and uncertainty

\begin{tabular}{|c|c|c|c|c|c|}
\hline \multirow[t]{2}{*}{ Discussion topic } & \multicolumn{3}{|c|}{ Expected scenarios (what they thought would happen) } & \multicolumn{2}{|c|}{ Desired scenarios (what they wanted to happen) } \\
\hline & Agreement & Disagreement & Uncertainty & Agreement & Disagreement \\
\hline $\begin{array}{l}\text { Overall Serengeti } \\
\text { ecosystem }\end{array}$ & $\begin{array}{l}\text { Population growth, } \\
\text { land-use conflicts, and } \\
\text { poaching as major } \\
\text { threats to the system } \\
\text { Significant changes } \\
\text { expected over the long } \\
\text { term }\end{array}$ & $\begin{array}{l}\text { The role of } \\
\text { international bodies } \\
\text { ("saviours" vs. } \\
\text { advisors) }\end{array}$ & $\begin{array}{l}\text { Climate change } \\
\text { Potential multiplicative } \\
\text { effect of multiple } \\
\text { threats } \\
\text { Technological } \\
\text { advancements and } \\
\text { development of } \\
\text { infrastructure } \\
\text { Tourism fluctuation } \\
\text { and satisfaction } \\
\text { Identification of model } \\
\text { to be followed for } \\
\text { achieving balance } \\
\text { between conservation } \\
\text { and development }\end{array}$ & $\begin{array}{l}\text { Serengeti preserved as } \\
\text { unique and iconic } \\
\text { ecosystem } \\
\text { Maintain tourism, } \\
\text { biodiversity, and } \\
\text { supporting livelihoods } \\
\text { as key goals of the } \\
\text { system } \\
\text { Integrated holistic } \\
\text { management approach } \\
\text { achieved for its } \\
\text { effective conservation }\end{array}$ & $\begin{array}{l}\text { Acceptable levels of } \\
\text { human engagement } \\
\text { (management and } \\
\text { resource use) in } \\
\text { ecosystem } \\
\text { Role of intrinsic vs. } \\
\text { instrumental reasons } \\
\text { for its conservation }\end{array}$ \\
\hline Bushmeat hunting & $\begin{array}{l}\text { Prevalence generally } \\
\text { increasing or, at least, } \\
\text { not decreasing } \\
\text { Done for both } \\
\text { subsistence and } \\
\text { commercial reasons } \\
\text { Difficulty in defining } \\
\text { and achieving } \\
\text { sustainable offtake }\end{array}$ & $\begin{array}{l}\text { Timeframe over which } \\
\text { bushmeat hunting will } \\
\text { be controlled }\end{array}$ & $\begin{array}{l}\text { Link between hunting } \\
\text { and poverty } \\
\text { Intervention } \\
\text { effectiveness } \\
\text { Observation } \\
\text { uncertainty } \\
\text { Role of urban demand } \\
\text { as driver } \\
\text { Effect of social change } \\
\text { in the future }\end{array}$ & $\begin{array}{l}\text { Mosaic of areas with } \\
\text { different protection } \\
\text { status (with hunting } \\
\text { not allowed inside the } \\
\text { NP) should be kept } \\
\text { Acceptability/tolerance } \\
\text { of bushmeat hunting } \\
\text { in the ecosystem, if at } \\
\text { sustainable levels }\end{array}$ & \\
\hline Ecological value & $\begin{array}{l}\text { Change is inevitable in } \\
\text { dynamic ecosystem } \\
\text { Significant changes not } \\
\text { expected in the short } \\
\text { term ( } 5 \text { years) }\end{array}$ & & $\begin{array}{l}\text { Environmental } \\
\text { uncertainty } \\
\text { Nonlinear dynamics } \\
\text { (tipping points) } \\
\text { System resilience }\end{array}$ & $\begin{array}{l}\text { Wildebeest migration } \\
\text { kept as key driver of } \\
\text { system function }\end{array}$ & $\begin{array}{l}\text { Type and magnitude of } \\
\text { acceptable change }\end{array}$ \\
\hline Poverty & $\begin{array}{l}\text { Improvements } \\
\text { unevenly distributed } \\
\text { within communities } \\
\text { and between areas } \\
\text { Lack of opportunities } \\
\text { for local communities } \\
\text { surrounding PAs }\end{array}$ & $\begin{array}{l}\text { Direction of the } \\
\text { expected general } \\
\text { trends of poverty } \\
\text { change }\end{array}$ & $\begin{array}{l}\text { Intervention } \\
\text { effectiveness } \\
\text { Link between } \\
\text { gradually increasing } \\
\text { wealth and natural } \\
\text { resource use } \\
\text { Effect of poverty } \\
\text { alleviation in } \\
\text { communities } \\
\text { surrounding PAs on } \\
\text { immigration }\end{array}$ & $\begin{array}{l}\text { Consensus about the } \\
\text { need to decrease } \\
\text { poverty } \\
\text { Equitable use of } \\
\text { resources }\end{array}$ & $\begin{array}{l}\text { Role of wildlife-related } \\
\text { activities (e.g., } \\
\text { tourism) for } \\
\text { community } \\
\text { development }\end{array}$ \\
\hline
\end{tabular}

findings to wider audiences, particularly the implementers and end users. Although a few respondents were relatively optimistic about the success of different ongoing interventions in controlling bushmeat hunting in the Serengeti, several participants were skeptical about the effectiveness of any of these interventions. However, according to the respondents, issues of spatial and temporal scale, baseline definition, data availability, and observation uncertainty hinder the measurement of actual intervention effectiveness.

The study participants mentioned a number of challenges preventing or limiting the effectiveness of ongoing conservation actions aimed at controlling bushmeat hunting and, more generally, preserving the Serengeti ecosystem. Although these issues are mainly related to the implementation part of the MSE framework, several affect the observation and assessment components as well. These issues can be broadly grouped in the following categories (see Appendix 3 for examples):

\section{Multiple goals and lack of integrated approaches}

Trade-offs among conservation, development, and tourism were often described as a major consideration when implementing management interventions ("at the same time, conservation projects need to maintain wildlife and improve livelihoods"), but also as a potential limitation to their effectiveness ("One solution could be a problem to another objective"). The lack of integrated approaches that consider these multiple goals together was identified as a major barrier to successful implementation ("There are development actors who are really pushing for a development scenario....and there are conservation actors who are pushing for 
a conservation scenario...it has to be some hybrid between these two"). According to the respondents, a common vision for the Serengeti is lacking, requiring more coordination among actors ("The management of the system itself...should sit together... because we have just a common goal but each one taking a different route").

\section{Adaptive responses to change under uncertainty}

The need for approaches that consider changes in system function over time was identified as a key requirement for the better management of the system, both for understanding its current dynamics and for being able to plan effective strategies under uncertainty, particularly due to effects of climate change ("Climate change... that's an unpredictable one"), development ("this road issue came out of the blue...we have to be prepared that things like this might happen"), technology ("poachers are using new ways of communications. Five or 10 years, there were no cell phones... Now, everyone uses it to escape rangers"), and social change ("political, cultural, and economic issues...the more they change, the more they tend to affect").

\section{Poor governance}

Poor governance was described as an important barrier to effective implementation in the Serengeti. The interviewed actors mentioned that improvements were required in several of its components, namely: participation ("local people should be central...not just being told what to do"), performance ("levels of bureaucracy that are completely unnecessary"), transparency ("there should be more transparency... revenues increasing but also being spent ... more invested back into conservation"), equity ("the way people are benefiting from conservation... is not really evenly distributed"), and rule of law ("livestock in protected areas... that is prohibited by law, but the enforcers are getting blockages"). According to the respondents, poor governance has been responsible, for example, for the lack of sustainability of interventions ("local people should have information so that, even if the project developers leave, they still own the process and will make it go on...but this is not happening"), implementation error ("the law is there...the judicial, the police, and whatever... the setup is there, but they are not functioning the right way"), and lack of trust of potential donors ("too corrupt and donors don't want to waste money").

\section{Institutional barriers}

Issues related to interactions between different groups and institutional processes were often described by the respondents as an important consideration. All participants were involved in ongoing collaborations across and within institutions. Many benefits arising from and driving these collaborations were listed, such as: exchange of knowledge and expertise, sharing resources, achieving common goals, and facilitating buy-in by other stakeholders. The respondents also identified a number of main challenges related to the institutional setting and interplay: lack of a common and long-term vision in both the regulations and interventions ("the regulations...this ecosystem is too big and managed by different guidelines...one regulation might affect the others"), difficulty in data access ("Accessing data not easy...all seems confidential to an organization"), difficulty in bringing together and reaching consensus with many stakeholders ("by the time you gathered everyone together and agreed on something, the budget is gone"), and mistrust between institutional actors ("during a presentation, there's sometimes doubt of the things they're presenting"). The effects of institutional complexity include, for example: inefficient use of resources ("you probably lose a lot of money in solving and tackling a single problem by different managers"), contradictory regulations ("you find laws are contradicting each other"), competition for external recognition ("everyone wants to take credit of the work...they want do it themselves"), and contradictory advice being given to local communities ("The forest officer goes to village and says you should protect an area...then goes the agricultural officer and says it's the most fertile and should be used for farming... without knowing the overall policies for forest conservation").

\section{Individual characteristics}

The specific individuals involved in the interventions and their personalities and other individual characteristics play an important role in the way projects develop. For example, commitment ("People usually come for $2-3$ years, they get sick of it, they get disillusioned, they leave"), diverse personalities ("conflicts between different types of personality...this can be disastrous if we fail to understand each other"), and reluctance to learn and adapt ("even if they don't have the knowledge to do it, they prefer to do it alone instead of integrating with others that know") were described as essential considerations in conservation implementation. One of the respondents described the importance of "conservation heroes" for successful conservation collaborations ("Those people sacrifice a huge amount of their other types of lives...Sacrifice the opportunity to live a life they're used to. You have to give these people credit.").

\section{Perceived value and use of scientific information}

Several respondents mentioned the abundant amount of research conducted in the Serengeti ("the Serengeti ecosystem is overresearched"), but most considered that there is a need for more information, given the ongoing changes in social and environmental conditions ("there's a lot to be studied and learned because context changes with time"), as well as the uncertain nature of the system and the scientific process ("Probably one of the best studied ecosystems but there are some things we just don't know").

The link between scientific information, both from research and monitoring, and management decisions in the Serengeti is, however, considered weak. According to the respondents, this might be due to: (a) researchers not sharing their findings widely ("we failed in sharing information with other audiences, and so impact has been minimal"); (b) researchers not addressing questions of management interest ("not many researchers go into management-oriented kind of research"); (c) data quality not being adequate for management decisions ("estimates with wide confidence limits... they are not a very good thing to set your hunting quotas"); (d) information not being perceived as valuable or trustworthy ("monitoring...it's just an academic exercise"). The recent use of long-term information about wildebeest population trends for informing decisions about the potential impacts of a road crossing the Serengeti was, however, occasionally mentioned as an example of scientific information influencing management decisions ("when there's emergency, things are more linked...like with this road issue...suddenly people started to think what's going to happen"). 


\section{Lack of proper incentives}

Inadequate incentives were mentioned as a key factor explaining discrepancies between expected and obtained outcomes from conservation interventions. According to the interviewed actors, these inadequate incentives affect the effectiveness of these interventions at the local community, decision-maker, and implementer levels. Targeting interventions at the individual vs. household or community level was one of the most frequently mentioned required improvements for implementation effectiveness in the area ("We need to use incentives... and not general incentives like construction of schools... tangible incentives that go directly to individuals").

\section{Relationships with local communities}

Lack of community participation during the planning of conservation interventions was frequently reported as a source of implementation error ("We, as managers, sometimes sit and think for people... maybe we bring them food because they are going there for meat...maybe we bring them chickens... this is not what they want!"). Most respondents agreed that the local communities were more considered, and engaged, in the ongoing conservation interventions than in the past but were skeptical about the actual level of engagement ("it has improved in policy but in reality not much"). Despite the need for improvements, most respondents emphasized that these approaches are essential for the sustainable future of the Serengeti ("The basic philosophy behind empowering communities to use wildlife is a very good approach").

\section{Institutional Complexity}

Institutional complexity was identified as a major barrier to conservation implementation in the scenario exercise. In the institutional analysis exercise, the study participants listed 13 institutions operating in the bushmeat hunting system in the Serengeti, of which FZS, TANAPA, TAWIRI, Grumeti Fund, and WD were the most commonly mentioned. Wildlife and social monitoring are mainly conducted by TAWIRI and FZS, although the respondents listed eight other institutions involved in these activities (Fig. 3). Twelve of the institutions (all except the universities) were listed as involved in the management of the system, both in terms of decision making and intervention implementation, of which TANAPA and WD were the most frequently mentioned. Based on the importance scores given by each respondent, TANAPA was the highest ranking institution for decision making and implementation, with respect to controlling bushmeat hunting, but obtained only $21 \%$ of the total importance score. The summed weighed score of the three highest ranking institutions (TANAPA, FZS, and TAWIRI) was 53\% (Appendix 3), suggesting that although the decision-making and implementation processes are shared mainly among these three organizations, responsibilities are also more broadly distributed among a number of institutions.

\section{Conservation Networks}

As expected given the number of institutions involved in the system, a large number of individuals from nine institutional groups (FZS, government - district level, government - national level, government - village level, other NGOs, TANAPA, TAWIRI, universities, and WMAs) were listed by the study participants as collaborators in projects related to conservation in the Serengeti. Of a total of 110 links among 66 people in the network, 30\% were connections to people working at FZS, followed by $21 \%$ to government (district and national levels), and $15 \%$ to TANAPA. Eighteen percent of the total links were intrainstitutional, suggesting that most collaborations occur across institutions.

Fig. 3. Main management challenges and institutions operating in the bushmeat hunting system, where they fit within the MSE framework and their perceived roles (font size is proportional to the number of respondents indicating a certain role for a specific institution).

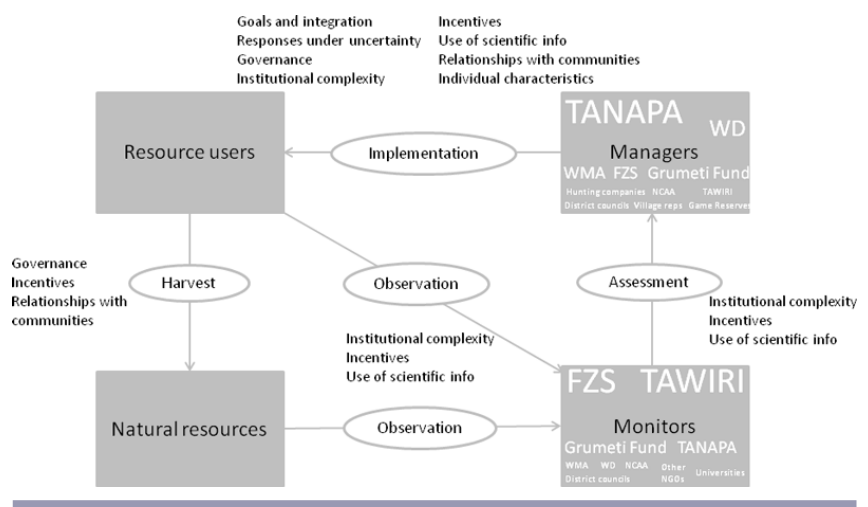

When looking at subsets of the overall network, obtained by asking the participants to indicate the main reasons for collaborating with each person (advice, influencing policy, or implementation), the policy network was the smallest (35 links), followed by the one for advice ( 52 links). The policy network had the lowest proportion of intra-institutional links, and the advice network had the highest ( $6 \%$ and $23 \%$, respectively), suggesting that collaboration has different functions between and within institutions. Additionally, the policy and advice networks were more disconnected than the implementation and general networks, with larger distances between actors (Fig. 4).

A few actors were consistently more influential and central than the others, particularly actors (14), (4), and (10), all of whom were from FZS (Fig. 4, Appendix 3). Actors from FZS play a central role in all network types, suggesting a key role played by this organization in multiple steps of the decision-making and implementation processes. As expected by the different nature of the work done by different institutions, the policy network was mainly composed of links to TANAPA and other governmental institutions, such as WD (63\% of total links), and the advice network was predominantly composed of links to NGOs and researchers from TAWIRI and universities ( $81 \%$ of total links). In the implementation network, $42 \%$ of the links were to NGOs and $25 \%$ were to TANAPA and other governmental institutions, suggesting an important role played by nongovernmental bodies.

\section{DISCUSSION}

Managing for resilience of a social-ecological system is only possible if both social and ecological dynamics and feedbacks are understood (Holling and Meffe 1996, Folke 2006). Social considerations are essential for understanding the feasibility of alternative actions and identifying the scope of conservation problems (Raymond and Knight 2013), but in traditional approaches to conservation and natural resource management, it 
Fig. 4. Social network of respondents for: (a) overall conservation activities; (b) advice and support; (c) influencing policy; and (d) implementation. For illustrative purposes, only one measure of influence (betweenness centrality) is shown. Each node (circle) represents an actor, node size is proportional to betweenness centrality (a measure of power/influence based on how many times an actor rests on a short path connecting two others who are themselves disconnected), width of lines represents frequency of interactions and colors represent organizations (see legend). Numbers represent the codes for the most influential actors as measured by their betweenness centrality.
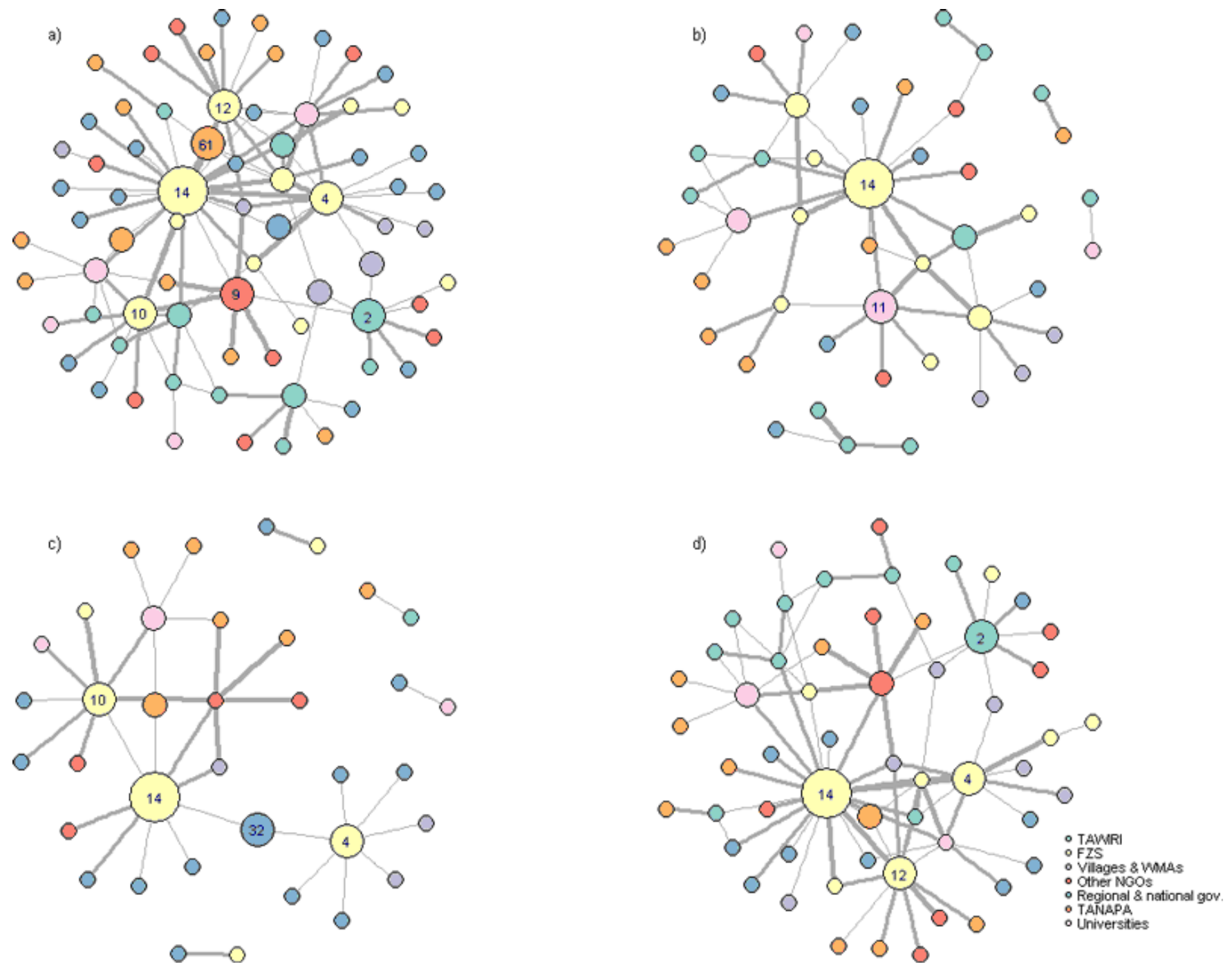

is often assumed that the "managers" and "monitors" are outside the system (Walker et al. 2002). As a conceptual framework, MSE is helpful in highlighting the relationships between actors, enabling reflection on the potential blockages in implementation of effective policy, and supporting the analysis of decision making in the face of uncertainty.

It is often assumed that natural resource management bodies can be modeled as unitary, rational, and well-informed actors (Young 1998), but our study suggests that this might be unrealistic and misleading; in the Serengeti, the relationships between institutions and individual actors involved in policy implementation are complex and diverse. The respondents in our study described contradictory regulations and advice as some of the negative effects of institutional complexity, whereas trade-offs among conservation, development, and tourism were often described as a potential limitation to intervention effectiveness. Our studies in the Serengeti indicate that understanding the complexity of behavior of key actors within management institutions is important for implementation, as the institutional setting and interactions between actors increase uncertainty and inertia in the system. For example, difficulties in accessing data collected by other organizations and reaching consensus among many different actors were often described as issues delaying intervention implementation.

Our study suggests that assessing and understanding the actual roles played by different individuals and institutions is essential 
for improving the resilience of governance structures. This can be enhanced by analyzing the structure of social networks (Bodin and Crona 2009). Network measures may be used to quantify structural characteristics and link them to a number of features, such as information dissemination, leadership, and trust (Bodin et al. 2006). Our results demonstrate the importance and centrality of an international NGO, FZS, in the conservation of the Serengeti, and in particular, the importance of very few individuals within FZS in bridging a range of institutions in all three arenas of interaction. Despite not having actual authority in the management of the system, FZS has been fundamental to the past and ongoing interventions, being present in the ecosystem since the late 1950s. Local social and political capital are, however, fundamental to local ownership of the processes, empowerment, fairness, and ultimately, system resilience (Adger et al. 2005a); capacity building, including members from local communities, should be further promoted in the Serengeti to reduce reliance on expatriate expertise. Reliance on very few individuals means that they potentially have a powerful influence and the ability to bind different groups together. However, it also reduces the robustness of the network. Adaptive governance of systems requires a large number of key people with different skills, who perform different leadership functions, enhancing the system's capacity to cope with uncertainty (Adger et al. 2005b).

Given that a lack of functional integrated approaches to natural resource management was identified as a main challenge to implementation, enhancing collaborative management is fundamental to promoting future sustainable strategies in the Serengeti. Comanagement, the joint management of natural resources, involves shared responsibilities and rights, recognizing the plurality of institutions in a governance structure (Plummer and Fitzgibbon 2004). Management decisions and implementation in the Serengeti are conducted by a number of institutional actors and, although there is no universal solution to the problems of resource management, governance features and institutional links affect conservation effectiveness (Acheson 2006, Armitage et al. 2012). Moreover, group size and heterogeneity influence prospects for collective action, often in nonlinear ways; for example, resources (such as time, money, and skills) may not be available in small groups, but the levels of interaction that generate trust and facilitate action decrease in large groups (Poteete and Ostrom 2004). Additionally, the respondents had generally similar views about the current and future status of the Serengeti but disagreed about how to address issues of conservation concern and were more uncertain about the effectiveness and actual outcomes of management interventions. Patterns found in fisheries can inform the design of governance structures; De Nooy (2013) found that centralized systems, such as found in the Serengeti, have more disagreement overall, and especially within stakeholder groups, whereas comanagement systems have more disagreement between groups.

Similarly to this study, difficulties in achieving multiple goals (e. g., conservation, development, and tourism) in social-ecological systems have been frequently described as challenges to implementation (Salafsky and Wollenberg 2000). It is important to identify and analyze the potential trade-offs involved in conservation initiatives (Hirsch et al. 2011), which can be done by applying tools such as MSE and AM. Management strategy evaluation has been used in situations in which several stakeholders had conflicting interests to identify objectives and alternative management strategies and help them choose among multiple options (e.g., Mapstone et al. 2008, Smith et al. 2008, Dichmont et al. 2013). For example, the need for local communities to be able to evaluate different options for resource ownership has been identified as one of the challenges to comanagement in the Serengeti (Kideghesho and Mtoni 2008), and an MSE approach could be used to promote consensus within a comanagement committee, such as the Serengeti Ecosystem Community Conservation Forum (SECCF). This has been recently created to promote collaboration between diverse stakeholders throughout the system and has the potential to be an effective platform for stakeholder participation and management (Randall et al., in press).

A key requirement for the development and implementation of adaptive approaches to natural resource management, such as MSE and AM, is the collection and use of information to learn about the system, which is then used to update conceptual models and to inform decisions about system management, closing the adaptive loop (Bunnefeld et al. 2011, Keith et al. 2011). However, this study shows that the links between system components and actors (monitoring, assessment, implementation), despite being essential for the adequate functioning of the management system, are currently not well established and fully functional in the Serengeti. Improving implementation (rather than research, monitoring, or assessment) was perceived as the priority, particularly given the amount of research already conducted in the area. This suggests that actually applying the knowledge accumulated over the last decades is still challenging. This is not unique to the Serengeti, having been described for a range of conservation projects as the "research-implementation gap" (Knight et al. 2008). Given the weak links reported between science and management decisions in the Serengeti, increasing the perceived value and use of scientific information should be a key priority for improving the management of the system (Pullin et al. 2004). The lack of monitoring and evaluation, leading to the uncertainty about the effectiveness of particular interventions aimed at reducing the exploitation of bushmeat species by local people (patrolling, microcredit schemes) highlighted by the respondents, makes it difficult to learn from previous and ongoing interventions, potentially creating conflict and mistrust between actors (Redpath et al. 2004). Implementing integrated monitoring programs encompassing both wildlife and resource users, and robustly evaluating ongoing interventions, would provide much-needed information of direct relevance to management decisions.

Although there were several areas of major difficulty in implementation of policies identified by respondents, the current management and monitoring system has the potential to work in a more integrated way. This was shown when a specific and easily identifiable threat to the system, a highway crossing the Serengeti, was proposed by central government. A swift and relatively coordinated response by international organizations and scientists was launched, based on a foundation of long-term research, which led to international concern and the identification of alternative options (Sinclair 2012). When faced with decisions about other more indirect or less easily measurable threats, such as climate change, the responses suggest that decision making may be more difficult and prolonged, and research insights may be harder to marshal in support of management. 


\section{CONCLUSION AND THE WAY FORWARD}

The need for decision tools for the quantitative description of the causal relationships and interactions between the various components of social-ecological systems has been increasingly recognized (Heinonen et al. 2012). These are, however, complex and data-demanding tasks. Quantitative models may be based on little empirical information and may be perceived by decision makers as of little use in real world decision making (Cooke et al. 2009). A qualitative investigation such as ours, using MSE as an underlying conceptual framework, could form the starting point for a quantitative model that couples social and ecological dynamics and would be more relevant to decision making than standard models rooted in a single discipline. For example, information about how different stakeholders interact (obtained from our network analysis), and how these interactions influence the decision-making process, could be used in an agent-based model of decision making, producing emergent behavior at higher levels (Rounsevell et al. 2012). Management strategy evaluation has a good track record of promoting participatory modeling (Röckmann et al. 2012), although to date the treatment of implementation uncertainty within MSE has lagged behind that of biological process uncertainty (Bunnefeld et al. 2011).

Incorporating the perspectives, values, and experiences of a wider range of actors would provide further insights into socialecological dynamics and interactions in the Serengeti. Our approach should be complemented by information about the factors driving resource user behavior and how resource users might react to different management strategies; only through a fully holistic approach that considers "resource users," "monitors," and "managers" (Fig. 1) will conservationists be able fully to address implementation uncertainty. The many challenges to conservation implementation are diverse, multidisciplinary, and complex, and require the integration of findings from psychology, sociology, and economics (St. John et al. 2010). Only by bringing these fields together in unified frameworks, such as MSE and AM, can conservation scientists be able to understand and provide tools to address the current conservation challenges.

Responses to this article can be read online at: http://www.ecologyandsociety.org/issues/responses. $\mathrm{php} / 6490$

\begin{abstract}
Acknowledgments:
We thank the interviewees for their time and participation in this study. AN was supported by the Portuguese Foundation for Science and Technology (FCT; doctoral grant SFRH/BD/43186/2008). $N B$ and EJMG were supported by the European Commission under the HUNT project of the 7th Framework Programme for Research and Technological Development, and EJMG by a Royal Society Wolfson Research Merit award. Jonathan Rhodes, Andrew Knight, and two anonymous reviewers gave valuable comments on the manuscript.
\end{abstract}

\section{LITERATURE CITED}

Acheson, J. M. 2006. Institutional failure in resource management. Annual Review of Anthropology 35:117-134.
Adams, W. M., D. Brockington, J. Dyson, and B. Vira. 2003. Managing tragedies: understanding conflict over common pool resources. Science 302:1915-1916.

Adger, W. N., K. Brown, and E. L. Tompkins. 2005a. The political economy of cross-scale networks in resource co-management. Ecology and Society 10(2): 9. [online] URL: http://www. ecologyandsociety.org/vol10/iss2/art9/

Adger, W. N., T. P. Hughes, C. Folke, S. R. Carpenter, and J. Rockström. 2005b. Social-ecological resilience to coastal disasters. Science 309:1036-1039. http://dx.doi.org/10.1126/ science. 1112122

Allen, C. R., J. J. Fontaine, K. L. Pope, and A. S. Garmestani. 2011. Adaptive management for a turbulent future. Journal of Environmental Management 92:1339-1345.

Allen, C. R., and L. H. Gunderson. 2011. Pathology and failure in the design and implementation of adaptive management. Journal of Environmental Management 92:1379-1384.

Arcese, P., J. Hando, and K. Campbell. 1995. Historical and present-day anti-poaching efforts in Serengeti. Pages 506-533 in A. R. E. Sinclair and P. Arcese, editors. Serengeti II: Dynamics, Management, and Conservation of an Ecosystem. Chicago University Press, Chicago.

Arlettaz, R., M. Schaub, J. Fournier, T. S. Reichlin, A. Sierro, J. E. M. Watson, and V. Braunisch. 2010. From publications to public actions: when conservation biologists bridge the gap between research and implementation. BioScience 60:835-842.

Armitage, D., R. de Loë, and R. Plummer. 2012. Environmental governance and its implications for conservation practice. Conservation Letters 5:245-255.

Armsworth, P. R., G. C. Daily, P. Kareiva, and J. N. Sanchirico. 2006. Land market feedbacks can undermine biodiversity conservation. Proceedings of the National Academy of Sciences 103:5403-5408. http://dx.doi.org/10.1073/pnas.0505278103

Ban, N. C., M. Mills, J. Tam, C. C. Hicks, S. Klain, N. Stoeckl, M. C. Bottrill, J. Levine, R. L. Pressey, T. Satterfield, and K. M. Chan. 2013. A social-ecological approach to conservation planning: embedding social considerations. Frontiers in Ecology and the Environment 11:194-202.

Bernard, H. R. 2011. Research methods in anthropology: qualitative and quantitative approaches. Fifth edition. AltaMira Press, Plymouth, UK.

Biggs, D., N. Abel, A. T. Knight, A. Leitch, A. Langston, and N. C. Ban. 2011. The implementation crisis in conservation planning: could "mental models" help? Conservation Letters 4:169-183.

Bodin, Ö., and B. I. Crona. 2009. The role of social networks in natural resource governance: what relational patterns make a difference? Global Environmental Change 19:366-374.

Bodin, Ö., B. Crona, and H. Ernstson. 2006. Social networks in natural resource management: what is there to learn from a structural perspective? Ecology and Society 11(2): resp2. [online] URL: http://www.ecologyandsociety.org/vol11/iss2/resp2/

Briassoulis, H. 2004. The institutional complexity of environmental policy and planning problems: the example of 
Mediterranean desertification. Journal of Environmental Planning and Management 47:115-135.

Bunnefeld, N., E. Hoshino, and E. J. Milner-Gulland. 2011. Management strategy evaluation: a powerful tool for conservation? Trends in Ecology and Evolution 26:441-447.

Butterworth, D. S., and A. E. Punt. 1999. Experiences in the evaluation and implementation of management procedures. ICES Journal of Marine Science 56:985-998. http://dx.doi. org/10.1006/jmsc.1999.0532

Cardinale, B. J., J. E. Duffy, A. Gonzalez, D. U. Hooper, C. Perrings, P. Venail, A. Narwani, G. M. Mace, D. Tilman, D. A. Wardle, A. P. Kinzig, G. C. Daily, M. Loreau, J. B. Grace, A. Larigauderie, D. S. Srivastava, and S. Naeem. 2012. Biodiversity loss and its impact on humanity. Nature 486:59-67.

Cochrane, K. 1999. Complexity in fisheries and limitations in the increasing complexity of fisheries management. ICES Journal of Marine Science 56:917-926. http://dx.doi.org/10.1006/jmsc.1999.0539

Cooke, I. R., E. H. A. Queenborough, S. A., Mattison, A. P. Bailey, D. L. Sandars, A. R. Graves, J. Morris, P. W. Atkinson, P. Trawick, R. P. Freckleton, A. R. Watkinson, and W. J. Sutherland. 2009. Integrating socio-economics and ecology: a taxonomy of quantitative methods and a review of their use in agro-ecology. Journal of Applied Ecology 46:269-277. http://dx.doi. org/10.1111/j.1365-2664.2009.01615.x

De Nooy, W. 2013. Communication in natural resource management: agreement between and disagreement within stakeholder groups. Ecology and Society 18(2): 44. [online] URL: http://www.ecologyandsociety.org/vol18/iss2/art44/ http://dx.doi. org/10.5751/ES-05648-180244

Dichmont, C. M., N. Ellis, R. H. Bustamante, R. Deng, S. Tickell, R. Pascual, H. Lozano-Montes, and S. Griffiths. 2013. Evaluating marine spatial closures with conflicting fisheries and conservation objectives. Journal of Applied Ecology 50:1060-1070.

Dobson, A. P., M. Borner, A. R. E. Sinclair, P. J. Hudson, T. M. Anderson, G. Bigurube, T. B. B. Davenport, J. Deutsch, S. M. Durant, R. D. Estes, A. B. Estes, J. Fryxell, C. Foley, M. E. Gadd, D. Haydon, R. Holdo, R. D. Holt, J. G. C. Hopcraft, R. Hilborn, G. L. K. Jambiya, M. K. Laurenson, L. Melamari, A. O. Morindat, J. O. Ogutu, G. Schaller, and E. Wolanski. 2010. Road will ruin Serengeti. Nature 467:272-273.

Folke, C. 2006. Resilience: the emergence of a perspective for social-ecological systems analyses. Global Environmental Change $16: 253-267$.

Fulton, E. A., A. D. M. Smith, D. C. Smith, and I. E. van Putten. 2011. Human behaviour: the key source of uncertainty in fisheries management. Fish and Fisheries 12:2-17.

Fyumagwa, R., E. Gereta, S. Hassan, J. R. Kideghesho, E. M. Kohi, J. Keyyu, F. Magige, I. M. Mfunda, A. Mwakatobe, J. Ntalwila, J. W. Nyahongo, V. Runyoro, and E. Røskaft. 2013. Roads as a threat to the Serengeti ecosystem. Conservation Biology 27:1122-1125.

Guerrero, A. M., R. R. J. McAllister, J. Corcoran, and K. A. Wilson. 2013. Scale mismatches, conservation planning, and the value of social-network analyses. Conservation Biology 27:35-44.
Harwood, J., and K. Stokes. 2003. Coping with uncertainty in ecological advice: lessons from fisheries. Trends in Ecology and Evolution 18:617-622.

Heinonen, J., J. Travis, S. M. Redpath, and M. A. Pinard. 2012. Combining socio-economic and ecological modelling to inform natural resource management strategies. In R. Seppelt, A. A. Voinov, S. Lange, and D. Bankamp, editors. Managing resources of a limited planet. Proceedings of the Sixth Biennial Meeting, 15 July 2012, International Environmental Modelling and Software Society (iEMSs), Leipzig, Germany. [online] URL: http://www.iemss.org/sites/iemss2012//proceedings/ H2 0759 Heinonen et al.pdf

Hilborn, R., P. Arcese, M. Borner, J. Hando, J. G. C. Hopcraft, M. Loibooki, S. Mduma, and A. R. E. Sinclair. 2006. Effective enforcement in a conservation area. Science 314:1266.

Hirsch, P. D., W. M. Adams, J. P. Brosius, A. Zia, N. Bariola, and J. L. Dammert. 2011. Acknowledging conservation trade-offs and embracing complexity. Conservation Biology 25:259-264.

Holland, J. 2007. Tools for institutional, political, and social analysis of policy reform: a sourcebook for development practitioners. The World Bank, Washington, D.C., USA.

Holling, C. S., and G. K. Meffe. 1996. Command and control and the pathology of natural resource management. Conservation Biology 10:328-337.

Holmern, T., E. Røskaft, J. Mbaruka, S. Y. Mkama, and J. Muya. 2002. Uneconomical game cropping in a community-based conservation project outside the Serengeti National Park, Tanzania. Oryx 36:364-372.

Homewood, K., D. Brockington, and S. Sullivan. 2010. Alternative view of Serengeti road. Nature 467:788-789.

Keith, D. A., T. G. Martin, E. McDonald-Madden, and C. Walters. 2011. Uncertainty and adaptive management for biodiversity conservation. Biological Conservation 144:11751178 .

Kideghesho, J. R., and P. E. Mtoni. 2008. The potentials for comanagement approaches in western Serengeti, Tanzania. Tropical Conservation Science 1:334-358.

Knight, A. T., R. M. Cowling, and B. M. Campbell. 2006. An operational model for implementing conservation action. Conservation Biology 20:408-419.

Knight, A. T., R. M. Cowling, M. Rouget, A. Balmford, A. T. Lombard, and B. M. Campbell. 2008. Knowing but not doing: selecting priority conservation areas and the researchimplementation gap. Conservation Biology 22:610-617. http://dx. doi.org/10.1111/j.1523-1739.2008.00914.X

Loibooki, M., H. Hofer, K. Campbell, and M. L. East. 2002. Bushmeat hunting by communities adjacent to the Serengeti National Park, Tanzania: the importance of livestock ownership and alternative sources of protein and income. Environmental Conservation 29:391-398.

Mapstone, B., L. Little, A. Punt, C. Davies, A. Smith, F. Pantus, A. McDonad, A. Williams, and A. Jones. 2008. Management strategy evaluation for line fishing in the Great Barrier Reef: 
balancing conservation and multi-sector fishery objectives. Fisheries Research 94:315-329.

Milner-Gulland, E. J. 2011. Integrating fisheries approaches and household utility models for improved resource management. Proceedings of the National Academy of Sciences 108:1741-1746. http://dx.doi.org/10.1073/pnas.1010533108

Ministry of Natural Resources and Tourism (MNRT). 1998. The wildlife policy of Tanzania. Ministry of Natural Resources and Tourism, Dar es Salaam, Tanzania.

National Bureau of Statistics Tanzania. 2006. Tanzania census 2002 - analytical report. National Bureau of Statistics Tanzania, Dar es Salaam, Tanzania.

Nelson, F., and S. O. Makko. 2005. Communities, conservation, and conflicts in the Tanzanian Serengeti. Pages 121-145 in B. Child and M. West Lyman, editors. Natural resources as community assets - lessons from two continents. Sand County Foundation, Madison, Wisconsin, USA and The Aspen Institute, Washington, D.C., USA. [online] URL: http://sandcounty.net/ assets/chapters/forward introduction.pdf

Nuno, A., N. Bunnefeld, L. C. Naiman, and E. J. Milner-Gulland. 2013. A novel approach to assessing the prevalence and drivers of illegal bushmeat hunting in the Serengeti. Conservation Biology 27:1355-1365. http://dx.doi.org/10.1111/cobi.12124

O'Malley, A. J., and P. V Marsden. 2008. The analysis of social networks. Health Services and Outcomes Research Methodology $8: 222-269$

Peterson, G. D., G. S. Cumming, and S. R. Carpenter. 2003. Scenario planning: a tool for conservation in an uncertain world. Conservation Biology 17:358-366.

Plagányi, E. E., I. van Putten, T. Hutton, R. A. Deng, D. Dennis, S. Pascoe, T. Skewes, and R. A. Campbell. 2013. Integrating indigenous livelihood and lifestyle objectives in managing a natural resource. Proceedings of the National Academy of Sciences 110:3639-3644. http://dx.doi.org/10.1073/pnas. 1217822110

Plummer, R., and J. Fitzgibbon. 2004. Co-management of natural resources: a proposed framework. Environmental Management 33:876-885.

Polasky, S., J. Schmitt, C. Costello, and L. Tajibaeva. 2008. Largerscale influences on the Serengeti ecosystem: national and international policy, economics and human demography. Pages 347-378 in A. R. E. Sinclair, C. Packer, J. M. Fryxell, and S. Mduma, editors. Serengeti III: human impacts on ecosystem dynamics. Chicago University Press, Chicago, Illinois, USA.

Poteete, A. R., and E. Ostrom. 2004. Heterogeneity, group size and collective action: the role of institutions in forest management. Development and Change 35:435-461.

Prell, C., K. Hubacek, and M. Reed. 2009. Stakeholder analysis and social network analysis in natural resource management. Society and Natural Resources 22:501-518.

Pullin, A. S., T. T. M. Knight, D. A. Stone, and K. Charman. 2004. Do conservation managers use scientific evidence to support their decision-making? Biological Conservation 119:245252.
R Core Team. 2012. R: A language and environment for statistical computing. R Foundation for Statistical Computing, Vienna, Austria. [online] URL: http://www.r-project.org/

Randall, D., A. Fischer, A. Nelson, M. Msuha, A. Lowassa, and C. Sandström. In press. Multiple functions and institutions: management complexity in the Serengeti ecosystem. In A. R. E. Sinclair, K. Metzger, S. Mduma, and J. Fryxell, editors. Serengeti $I V$ : sustaining biodiversity in a coupled human-natural system. Chicago University Press, Chicago, Illinois, USA.

Raymond, C. M., and A. T. Knight. 2013. Applying social research techniques to improve the effectiveness of conservation planning. BioScience 63:320-321. http://dx.doi.org/10.1525/ bio.2013.63.5.2

Redpath, S. M., B. Arroyo, F. M. Leckie, P. Bacon, N. Bayfield, R. J. Gutierrez, and S. J. Thirgood. 2004. Using decision modeling with stakeholders to reduce human-wildlife conflict: a raptorgrouse case study. Conservation Biology 18:350-359.

Redpath, S. M., J. C. Young, A. Evely, W. M. Adams, W. J. Sutherland, A. Whitehouse, A. Amar, R. A. Lambert, J. D. C. Linnell, A. Watt, and R. J. Gutiérrez. 2013. Understanding and managing conservation conflicts. Trends in Ecology and Evolution 28:100-109. http://dx.doi.org/10.1016/j.tree.2012.08.021

Röckmann, C., C. Ulrich, M. Dreyer, E. Bell, E. Borodzicz, P. Haapasaari, K. H. Hauge, D. Howell, S. Mäntyniemi, D. Miller, G. Tserpes, and M. Pastoors. 2012. The added value of participatory modelling in fisheries management - what has been learnt? Marine Policy 36:1072-1085.

Rounsevell, M. D. A., D. T. Robinson, and D. Murray-Rust. 2012. From actors to agents in socio-ecological systems models. Philosophical Transactions of the Royal Society. Series B, Biological Sciences 367:259-269. http://dx.doi.org/10.1098/ rstb.2011.0187

Salafsky, N., and E. Wollenberg. 2000. Linking livelihoods and conservation: a conceptual framework and scale for assessing the integration of human needs and biodiversity. World Development 28:1421-1438.

Serengeti Ecosystem Management Project (SEMP). 2006. Report of a study of stakeholders of the Serengeti ecosystem. Serengeti Ecosystem Management Project, Frankfurt, Germany.

Shetler, J. B. 2007. Imagining Serengeti: a history of landscape memory in Tanzania from earliest times to the present. Ohio University Press, Athens, Ohio, USA.

Sinclair, A. R. E. 2003. Mammal population regulation, keystone processes and ecosystem dynamics. Philosophical Transactions of the Royal Society of London. Series B, Biological Sciences 358:1729-1740.

Sinclair, A. R. E. 2012. Serengeti story: life and science in the world's greatest wildlife region. Oxford University Press, Oxford, $\mathrm{UK}$.

Sinclair, A. R. E., S. Mduma, J. G. C. Hopcraft, J. M. Fryxell, R. Hilborn, and S. J. Thirgood. 2007. Long-term ecosystem dynamics in the Serengeti: lessons for conservation. Conservation Biology 21:580-590. 
Smith, A. 1999. Implementing effective fisheries-management systems - management strategy evaluation and the Australian partnership approach. ICES Journal of Marine Science 56:967979. http://dx.doi.org/10.1006/jmsc. 1999.0540

Smith, A. D. M., D. C. Smith, G. N. Tuck, N. Klaer, A. E. Punt, I. Knuckey, J. Prince, A. Morison, R. Kloser, M. Haddon, S. Wayte, J. Day, G. Fay, F. Pribac, M. Fuller, B. Taylor, and L. R. Little. 2008. Experience in implementing harvest strategies in Australia's south-eastern fisheries. Fisheries Research 94:373379.

St. John, F. A. V., G. Edwards-Jones, and J. P. G. Jones. 2010. Conservation and human behaviour: lessons from social psychology. Wildlife Research 37:1-10.

Thirgood, S. J., A. Mosser, S. Tham, J. G. C. Hopcraft, E. Mwangomo, T. Mlengeya, M. Kilewo, J. M. Fryxell, A. R. E. Sinclair, and M. Borner. 2004. Can parks protect migratory ungulates? The case of the Serengeti wildebeest. Animal Conservation 7:113-120. http://dx.doi.org/10.1017/S1367943004001404

Thirgood, S., C. Mlingwa, E. Gereta, V. Runyoro, R. Malpas, K. Laurenson, and M. Borner. 2008. Who pays for conservation? Current and future financing scenarios for the Serengeti ecosystem. Pages 443-470 in A. R. E. Sinclair, C. Packer, and S. A. R. Mduma, editors. Serengeti III: human impacts on ecosystem dynamics. Chicago University Press, Chicago, Illinois, USA.

United Nations Development Programme (UNDP). 2012. Protected areas. Chapter 4 in UNDP. International guidebook of environmental finance tools - a sectoral approach: protected areas, sustainable forests, sustainable agriculture and pro-poor energy. UNDP, New York, New York, USA. [online] URL: http://www. undp.org/content/undp/en/home/librarypage/environment-energy/ environmental_finance/international-guidebook-of-environmentalfinance-tools-/

Walker, B., S. Carpenter, J. Anderies, N. Abel, G. S. Cumming, M. Janssen, L. Lebel, J. Norberg, G. D. Peterson, and R. Pritchard. 2002. Resilience management in social-ecological systems: a working hypothesis for a participatory approach. Conservation Ecology 6:14.

Walker, B., and M. Janssen. 2002. Rangelands, pastoralists and governments: interlinked systems of people and nature. Philosophical Transactions of the Royal Society of London. Series B, Biological Sciences 357:719-725.

Walters, C. J. 2007. Is adaptive management helping to solve fisheries problems? AMBIO: A Journal of the Human Environment 36:304-307.

Watson, R. M. 1965. Game utilization in the Serengeti: preliminary investigations. I. The British Veterinary Journal 121:540-546.

Westgate, M. J., G. E. Likens, and D. B. Lindenmayer. 2013. Adaptive management of biological systems: a review. Biological Conservation 158:128-139.

Young, O. R. 1998. Institutional uncertainties in international fisheries management. Fisheries Research 37:211-224. 


\section{Appendix 1. Questionnaire}

Name:

Organization(s):

Main place of work:

Nationality:

Age: Sex:

How long have you been working in the Serengeti?

$$
\begin{aligned}
& <1 \text { year } \\
& 2-5 \text { years } \\
& 6-10 \text { years } \\
& >10 \text { years }
\end{aligned}
$$

Could you please briefly describe your academic and disciplinary background?

\section{What type of work best describes your work within your organization?}

$\square$ Administration/Management

$\square$ Program coordination/Project management

$\square$ Analysis

Field work

$\square$ Research

Other:

\section{Area of work (please choose as many as apply):}

$\square$ Academic

Anti-poaching

Wildlife monitoring

Livelihood alternatives \& engagement with local communities

$\square$ Tourism

Other: 
Scenario-building exercise: Now, I'm going to ask you to briefly describe what you think it's going to happen, and what you'd like to happen, in the Serengeti in the future. What are the constraints to going from expected to ideal situation?

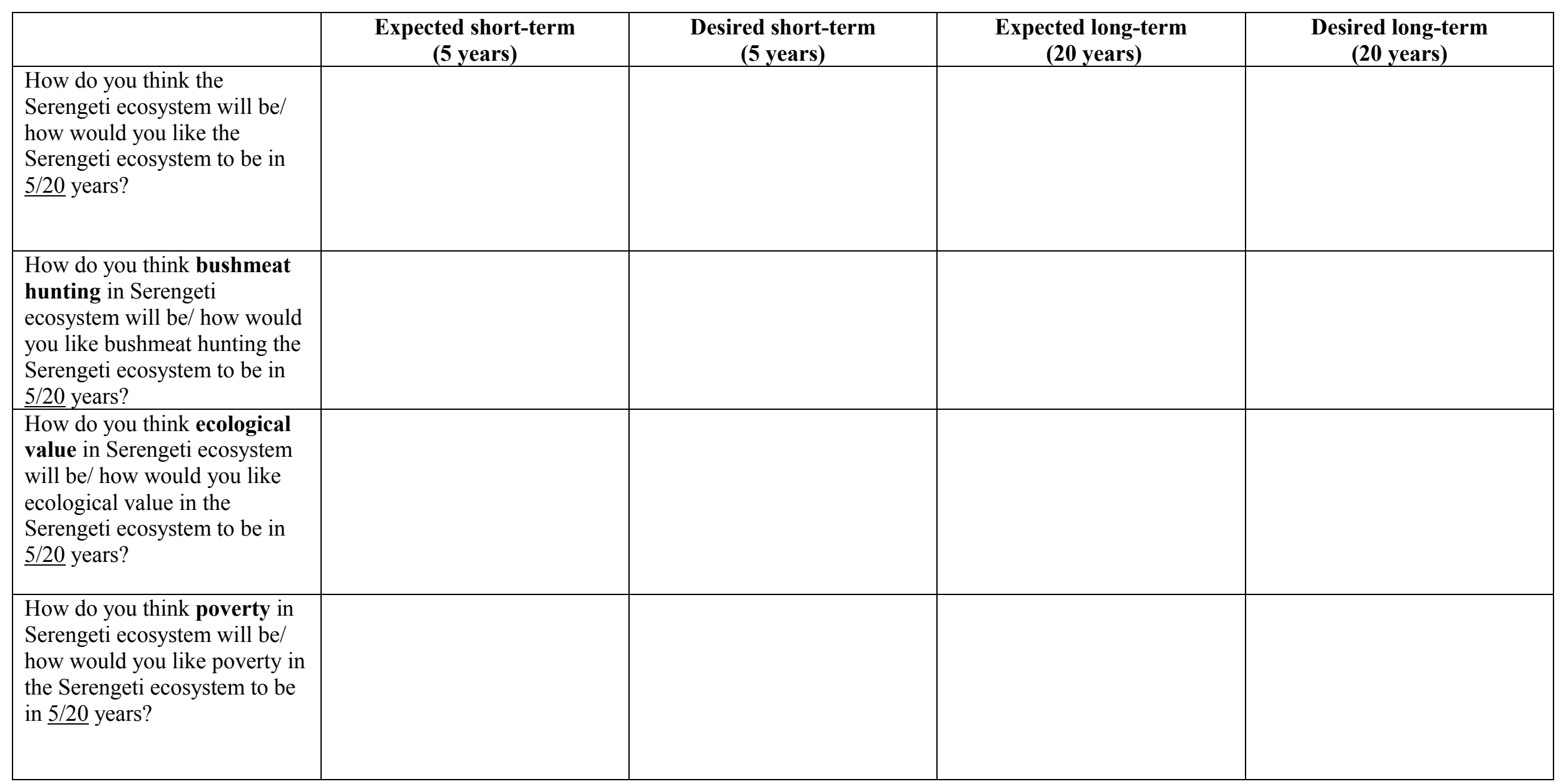


Institutional analysis exercise: Please list institutions operating in the bushmeat hunting system in the Serengeti, where do you think they play a role in our MSE framework and their importance for decision-making and intervention implementation

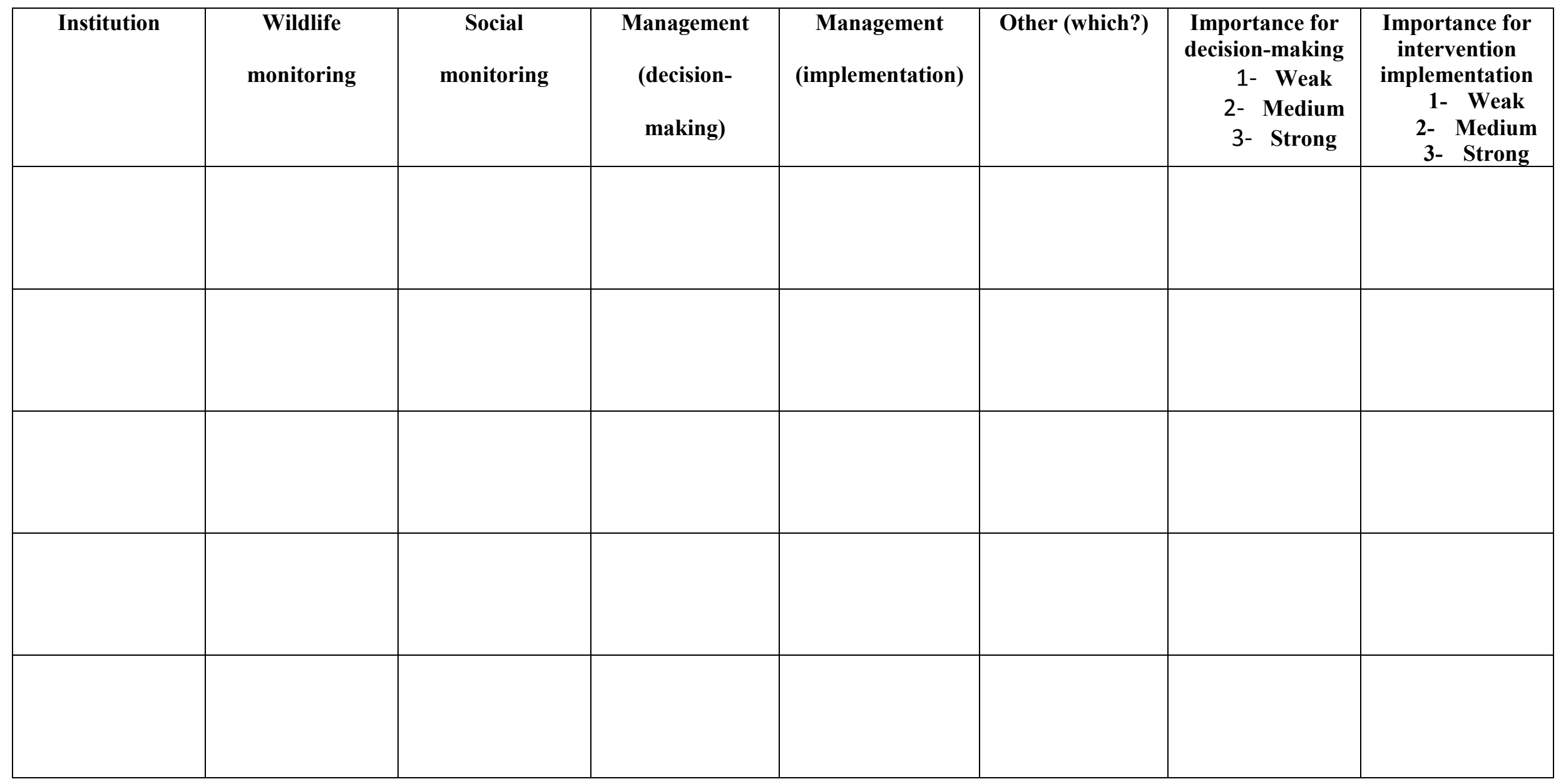




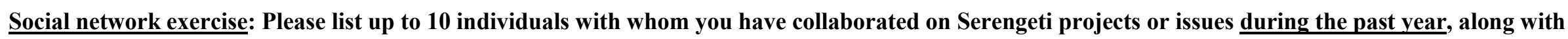
the name of their organization, and frequency and nature of collaboration.

\begin{tabular}{|c|c|c|c|c|c|c|c|c|c|}
\hline \multirow{2}{*}{$\begin{array}{c}\text { Name } \\
\text { (First name }+ \\
\text { surname) }\end{array}$} & \multirow[b]{2}{*}{ Organization } & \multicolumn{3}{|c|}{$\begin{array}{c}\text { How often do you communicate } \\
\text { with this person about Serengeti } \\
\text { projects or issues? }\end{array}$} & \multicolumn{5}{|c|}{ What are your main reasons for collaborating with this person? } \\
\hline & & $\begin{array}{l}\text { Less than } \\
\text { monthly }\end{array}$ & $\begin{array}{l}\text { Monthly or } \\
\text { every } 2 \\
\text { weeks }\end{array}$ & $\begin{array}{l}\text { Daily or } \\
\text { weekly }\end{array}$ & $\begin{array}{c}\text { Advice or } \\
\text { technical } \\
\text { support }\end{array}$ & $\begin{array}{c}\text { Influencing } \\
\text { policy } \\
\text { decision- } \\
\text { making } \\
\end{array}$ & $\begin{array}{c}\text { Project } \\
\text { management }\end{array}$ & $\begin{array}{c}\text { Project } \\
\text { implementation }\end{array}$ & Other (which?) \\
\hline & & & & & & & & & \\
\hline & & & & & & & & & \\
\hline & & & & & & & & & \\
\hline & & & & & & & & & \\
\hline & & & & & & & & & \\
\hline & & & & & & & & & \\
\hline & & & & & & & & & \\
\hline & & & & & & & & & \\
\hline & & & & & & & & & \\
\hline & & & & & & & & & \\
\hline
\end{tabular}

Is there anyone else you would like to add to this list? 



\section{Appendix 2. Topic guide for semi-structured interviews}

This is an outline of key issues and areas of questioning used to structure the discussion with each participant, with its use (flow and wording) guided by the experiences of the respondent:

1. In your opinion, what are the top 5 threats to the system? (If bushmeat hunting is not mentioned, ask where it fits)

2. Looking at the MSE framework (show Figure 1), is there anything you would add to this framework? (do you think all main processes and actors in the system are represented?)

3. What are the main benefits of working with other organizations operating in this system? (Ask specific examples). What about challenges? (Ask specific examples)

4. Where do you think the main information gaps in this system are? Is that currently being addressed? How or why not?

5. What prevents the exchange of information and knowledge between organizations?

6. What constrains applying information/knowledge when implementing management? (Ask specifically about monitoring wildlife and translating this into management changes)

7. Do you think the current management strategies have been effective at controlling bushmeat hunting? (Ask specific examples of strategies, outcomes and why they think that's the case)

8. Do you think the current management strategies have been implemented as planned? Why? (Ask examples of discrepancies between decisions and their realization)

9. Do you think it would be possible to test different management strategies? How? Any expected challenges? (mention modelling if they don't)

10. Do you feel the local communities are being engaged and considered in the current management strategies? (Assess perceptions of what local communities need and should be entitled to)

11. Thank you for your time. Is there anything else you'd like to add or comment? 


\section{Appendix 3. Supporting material providing more detailed and/or quantitative information from the results presented in the manuscript.}

Table A1.3. Categories of top threats to the Serengeti ecosystem mentioned by the study participants and the number of respondents (out of 19) reporting each specific threat.

\begin{tabular}{lc}
\hline \multicolumn{1}{c}{ Threats } & Frequency \\
\hline Human population growth & 12 \\
Land-use conflicts and encroachment (e.g. & 10 \\
overstocking of livestock, grazing inside & \\
protected areas) & 10 \\
Poaching (bushmeat and ivory) & 8 \\
Climate change and environmental stress & 6 \\
Development, infrastructures and tourism & \\
(e.g. roads, railways) & 6 \\
Poor management and governance (e.g. & 3 \\
dependence on unstable funding; institutional & 3 \\
Mining & \\
complexity; instability in policies) & \\
Poverty and lack of opportunities & \\
Diseases (human/wildlife/livestock) &
\end{tabular}


Table A2.3. Example quotes illustrating the main types of issues affecting conservation implementation in the Serengeti, as described by the study participants.

\begin{tabular}{|c|c|c|}
\hline Type of issue & Challenges described & Quotes from the interviews \\
\hline \multirow[t]{3}{*}{$\begin{array}{l}\text { Multiple goals and lack of } \\
\text { integrated approaches }\end{array}$} & $\begin{array}{l}\text { trade-offs between } \\
\text { tourism, development } \\
\text { and conservation }\end{array}$ & $\begin{array}{l}\text { "Tourists in the Serengeti come } \\
\text { for wildlife... in their natural } \\
\text { habitat. If we put up } \\
\text { infrastructures, we're obviously } \\
\text { jeopardising the resources that we } \\
\text { accrue from tourism" } \\
\text { "if we don't get money, we can't } \\
\text { put up anti-poaching activities. } \\
\text { Tourism is the main source of } \\
\text { revenue" } \\
\text { "the spiritual and traditional } \\
\text { ideas of having them [wildlife] as } \\
\text { their heritage is much better than } \\
\text { one based on making money from } \\
\text { tourism because that can go up } \\
\text { and down" }\end{array}$ \\
\hline & $\begin{array}{l}\text { coordination between } \\
\text { actors }\end{array}$ & $\begin{array}{l}\text { "The management of the system } \\
\text { itself...should sit together...because } \\
\text { we have just a common overall } \\
\text { goal but each one taking a } \\
\text { different route" }\end{array}$ \\
\hline & balance of objectives & $\begin{array}{l}\text { "we are concentrating so much } \\
\text { inside the park... and we are } \\
\text { forgetting about the surrounding } \\
\text { communities" }\end{array}$ \\
\hline $\begin{array}{l}\text { Adaptive responses to change } \\
\text { under uncertainty }\end{array}$ & $\begin{array}{l}\text { unexpected threats and } \\
\text { outcomes }\end{array}$ & $\begin{array}{l}\text { "this road issue came out of the } \\
\text { blue... we have to be prepared that } \\
\text { things like this might happen" }\end{array}$ \\
\hline \multirow{4}{*}{ Poor governance } & participation & $\begin{array}{l}\text { "local people should be } \\
\text { central...not just being told what } \\
\text { to do" }\end{array}$ \\
\hline & performance & $\begin{array}{l}\text { "levels of bureaucracy that are } \\
\text { completely unnecessary" }\end{array}$ \\
\hline & transparency & $\begin{array}{l}\text { "there should be more } \\
\text { transparency... revenues } \\
\text { increasing but also being spent ... } \\
\text { more invested back into } \\
\text { conservation" }\end{array}$ \\
\hline & equity & "the way people are benefiting \\
\hline
\end{tabular}


from conservation ... is not really

evenly distributed"

rule of law

"livestock in protected areas... that

is prohibited by law but the

enforcers are getting blockages"

lack of a common and

"this ecosystem is too big and

long-term vision in the

managed by different

regulations and

interventions

guidelines...one regulation might

difficulty in data

affect the others"

"Accessing data not easy... all

access

seems confidential to an

organization"

Institutional barriers

difficulty in bringing

"by the time you gathered

together and reaching

everyone together and agreed on

consensus with many

something, the budget is gone"

stakeholders

mistrust between

institutional actors

"during a presentation, there's

sometimes doubt of the things

they're presenting"

diverse personalities

"conflicts between different types

of personality...this can be

disastrous if we fail to understand

each other"

commitment

"People usually come for 2-3

Individual characteristics years, they get sick of it, they get disillusioned, they leave"

reluctance to learn and "even if they don't have the adapt

knowledge to do it, they prefer to do it alone instead of integrating with others that know"

researchers not sharing their findings widely

researchers not addressing questions of

Perceived value and use of scientific information

management interest

data quality not being adequate for management decisions information not being perceived as valuable or trustworthy

economic drivers in

Lack of proper incentives quota-setting "we failed in sharing information with other audiences and so impact has been minimal" "not many researchers go into management-oriented kind of research" "estimates with wide confidence limits... they are not a very good thing to set your hunting quotas" "monitoring...it's just an academic exercise"

"they were just halved because people wanted to make more money" 
commitment to actual implementation

time scale "if you have a plan but it's just a piece of paper and no one is holding it to it, there's absolutely no incentive to follow it" " the interventions are frequently short-term and very dependent on grants and specific people... and this lack of continuity results in loss of trust in these interventions"

perceptions of "strategies should focus on conservation by local communities expectations about the interventions

effectiveness

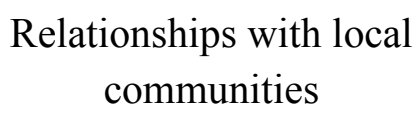

insufficient participation of local communities engagement of "elites"

scale of the decisions

lack of organizational and intellectual skills showing benefits of conservation to local communities... we have failed to show them these benefits" "local communities have high expectations most of the time ... that affects the intervention. They expect instant money" "community-based conservation is simply not working! And one of the reasons why it doesn't work is because it's naive." "maybe there's a better way... if people sit together with the villagers and talk about it and how to go about it"

"if we engage, it's only the political figures from the local communities" "we should keep them [local communities] out of making a local decision on a national issue" "they have not participated in the decisions because they were not able to understand" 
Table A3.3. Main institutions operating in the bushmeat hunting system and their perceived proportional importance for decision-making and intervention implementation when controlling bushmeat hunting, according to the study participants.

\begin{tabular}{|c|c|c|}
\hline Institution & $\begin{array}{l}\text { Importance for } \\
\text { decision-making }\end{array}$ & $\begin{array}{l}\text { Importance for } \\
\text { implementation }\end{array}$ \\
\hline Tanzania National Parks (TANAPA) & $21.8\left(1^{\mathrm{st}}\right)$ & $20.8\left(1^{\mathrm{st}}\right)$ \\
\hline Frankfurt Zoological Society (FZS) & $17.9\left(2^{\mathrm{nd}}\right)$ & $20.2\left(2^{\text {nd }}\right)$ \\
\hline $\begin{array}{l}\text { Tanzania Wildlife Research Institute } \\
\text { (TAWIRI) }\end{array}$ & $13.5\left(3^{\mathrm{rd}}\right)$ & $12.5\left(3^{\mathrm{rd}}\right)$ \\
\hline Wildlife Division (WD) & $11.5\left(4^{\text {th }}\right)$ & $10.1\left(5^{\text {th }}\right)$ \\
\hline Grumeti Fund & $8.3\left(5^{\text {th }}\right)$ & $10.7\left(4^{\text {th }}\right)$ \\
\hline $\begin{array}{l}\text { Wildlife Management Areas (WMAs; Ikona } \\
\text { and Makao) }\end{array}$ & $5.1\left(6^{\mathrm{th}}\right)$ & $5.4\left(6^{\mathrm{th}}\right)$ \\
\hline District Council (e.g. District Game Office) & $4.5\left(7^{\mathrm{th}}\right)$ & $4.8\left(8^{\text {th }}\right)$ \\
\hline $\begin{array}{l}\text { Ngorongoro Conservation Area Authority } \\
\qquad \text { (NCAA) }\end{array}$ & $4.5\left(7^{\mathrm{th}}\right)$ & $3.6\left(9^{\mathrm{th}}\right)$ \\
\hline Other NGOs (e.g. WWF, Friedkin & & \\
\hline Conservation Fund, AWF, Jane Goodall & $3.8\left(9^{\mathrm{th}}\right)$ & $2.4\left(10^{\text {th }}\right)$ \\
\hline Institute) & & \\
\hline Villages + local governments & $3.2\left(10^{\text {th }}\right)$ & $5.4\left(6^{\text {th }}\right)$ \\
\hline Game Reserves (Ikorongo-Grumeti and & $3.2\left(10^{\text {th }}\right)$ & $1.2\left(12^{\text {th }}\right)$ \\
\hline Maswa) & & \\
\hline Hunting company (TGT) & $1.3\left(12^{\mathrm{th}}\right)$ & $1.8\left(11^{\text {th }}\right)$ \\
\hline Universities & $1.3\left(12^{\text {th }}\right)$ & $1.2\left(12^{\text {th }}\right)$ \\
\hline
\end{tabular}


Table A4.3. Characteristics of social networks in Serengeti projects of study respondents.

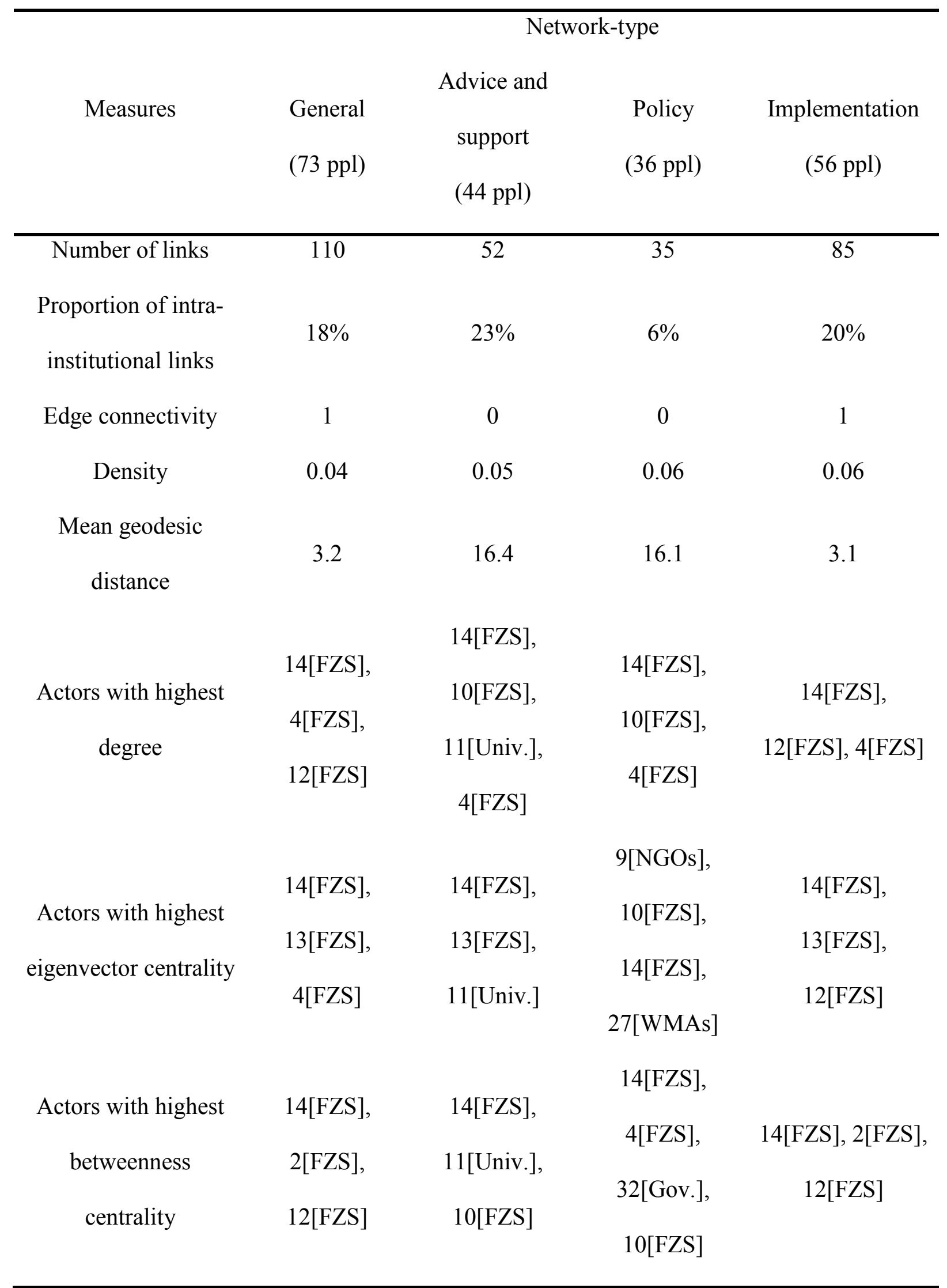

